\title{
RUMOUR AND HUMOUR IN \#WHEREIsPUTIN AND \#PUTINUMER: GLOBAL MEDIA AND THE CULT OF PUTIN
}

\author{
Liisi Laineste \\ Department of Folkloristics \\ Estonian Literary Museum, Estonia \\ e-mail: liisi@folklore.ee \\ Eda Kalmre \\ Department of Folkloristics \\ Estonian Literary Museum, Estonia \\ e-mail:eda@folklore.ee
}

\begin{abstract}
The article analyses rumours about Putin's disappearance from the public eye during the ten-day period in March 2015. Parallels with earlier rumours about Russian leaders before Putin are thus revealed and differences between English and Russian sources of information are pointed at.

The data presented here comes from both traditional and social media: the global official news coverage of Putin's disappearance, and the unofficial information spread in social media via Twitter hashtags \#WhereIsPutin and \#PutinUmer. Using this data, the authors describe the differences between English- and Russian-language social media sources and indicate the recurring and more influential belief motifs in the stories told about the political leaders in Russia in the junction of various genres (above all rumour, humour, and news). The analysis sheds light on the inner workings of rumour and humour in social media. The comparison shows that even if the world is a 'global village' and news, travelling fast, quickly become known around the world, there is a fissure between the content and the ways particular events or cases get represented in the official media outlets and social media. The differences arise from the cultural and historical context of the producers and consumers of the news: collective memory, folklore, vernacular belief, etc.
\end{abstract}

Keywords: conspiracy theories, contemporary legend, humour, infotainment, newslore, Putin, rumour, Russia 
Twenty-first-century Ostankino mixes show business and propaganda, ratings with authoritarianism. And at the centre of the great show is the President himself, created from a no one, a gray fuzz via the power of television, so that he morphs as rapidly

as a performance artist among his roles of soldier, lover, barechested hunter, businessman, spy, tsar, superman. 'The news is the incense by which we bless Putin's actions, make him the President,' $T V$ producers and political technologists liked to say. Peter Pomerantsev (2014) ${ }^{1}$

\section{INTRODUCTION}

On the evening of January 26,2015 , Russian social media started to buzz with stories about Vladimir Putin (b. 1952), President of Russia, having allegedly had a heart attack. The rumour started from the news about Moscow Red Square being closed off by the federal security forces on that day. Rumours about Vladimir Putin's health problems stopped after the head of the state was seen again in public, chairing a meeting of the Security Council of the Russian Federation. Although these stories lasted for a very short time, they caused considerable reverberation in the unofficial media channels dominated by grassroots journalism. ${ }^{2}$ However, it is worth noting that this was neither the first nor the last time that similar speculations about Vladimir Putin stirred up a storm in both online and offline media channels in Russia; furthermore, these stories had also been circulating about other Russian leaders.

In March 2015, Putin disappeared from the view of the media for more than a week, which is a long time considering that since his ascent to authoritarian power Putin has been a star figure in the media, "reigning on the screen unchallenged" (Sperling 2016; Abdullaev 2010). Immediately, numerous speculations and rumours arose concerning the reasons of his disappearance. Analysing this gives an insight into the workings of the contemporary information society and its need for infotainment, but even more so into the long-running beliefs held by the people who are discussing the topic. Next to the more traditional media, alternative information channels - e.g. social media outlets - are available nowadays. Participatory media in the form of citizen journalism are booming and ideas about the truth-value of news are changing as well. ${ }^{3}$ However, online and offline media are followed by different audiences (Oates \& Lokot 2013): the choice of media channels is more a matter of intent and preferences than opportunity (the same can be said about the media in other authoritarian systems; see, e.g., Astapova 2015: 23). 
This article addresses the media behaviour and rumours concerning Putin's disappearance from the public eye during the ten-day period in March 2015, and discusses them in the light of classical negatory rumours and legend $\mathrm{s}^{4}$ from history. The theoretical backdrop for the discussion is set by folkloristic theories of rumour and conspiracy, but also those of online communication and humour. The data analysed here consists of two equally important sources: global news coverage of Putin's disappearance, and the information spread in social media via English- and Russian-language Twitter hashtags \#WhereIsPutin and \#PutinUmer. Based on our results, we describe how news spread on the global arena, compare the English- and Russian-language social media sources dealing with the topic, and, last but not least, show what the reoccurring (and most influential) motives are in the stories told about the political leaders in Russia, and how they reappear in present-day internet folklore concerning Putin. The analysis sheds light on the inner workings of rumour and humour in social media, taking the incident of Putin gone missing as a case in point.

\section{RUMOURS ABOUT THE (ETERNAL) LIFE OF THE HERO}

"Life would be boring without rumours," stated Putin to reporters in his first public event since March 15, referring to rumours about his 10-day absence earlier that month (Birnbaum \& Murphy 2015). Earlier observations confirm that the more prominent an event or person is, the more folklore it generates: "a story that is strong on prominence and novelty but weak on impact is likelier to generate a folkloric response... [it] is likelier to generate newslore that targets the news media" (Frank 2011: 168). Shekshnia, Puffer, and McCarthy (2009: 325) have described how the leaders of the society as well as minorities use mythology in the broad sense (stories, jokes, tales, songs, supernatural events, and characters) to influence and educate people. This mythology reflects culture and is accepted in the eyes of most of the people. The observation can be easily applied to present-day Russia as well.

But prominence in the present-day media scene also means visual presence and power. All the news almost exclusively requires providing a visual - better yet, audio-visual - account of the event. The importance of the visual is deeply rooted in evolutionary processes, but online media has brought it into the limelight. Mieke Bal (2003: 11) has noted that a "vision is always implicated in a knot of power and knowledge". Seeing is believing, as the saying goes, and our reality depends on what we are shown in the media, whereas the accessibility to information is in turn controlled by power. Sanja Bjelica (2015) connects the furore following Putin's media absence in March 2015 to 
the centralised power established in Putin's figure - his actual, everyday physiological presence in photographs and film. In politics appearance is everything, and it is even truer in the image-centred culture of the present times. ${ }^{5}$ Putin has been turned into a spectacle (Simons 2014): what we know about Putin is dependent on how he appears in the media. In the official media channels, such images are presented in an overly positive context. We are to believe the attractiveness, virility, masculinity, and firmness of the autocrat, as they all are integral parts of the image of the man (see Figs. 11-13). This illustrates the point that visual representation and what it conveys - intentionally or unintentionally - is one of the prime mechanisms of meaning-making (Demski \& Laineste \& Baraniecka-Olszewska 2015).

In order to understand and analyse the diversity of today's highly visual and humorous culture (e.g. memes on the Internet), we need to know its folkloric foundation and building blocks.

Rumours have always abounded in Russia from the Tsarist era to the postSoviet times (Ortmann \& Heathershaw 2012: 551). Rumours were especially predominant in the Soviet Union, particularly in the period up to Stalin's death, where they were indeed the main substitute for news. This situation lasted until the collapse of the Soviet regime (Kalmre 2013a: 17). Even though spreading anti-regime rumours (as well as telling jokes) has always been a risky endeavour under totalitarian circumstances (Oring 2016: 110, 128, and elsewhere; Kalmre 2013a: 18-19), this has never stopped people from sharing them. Regardless of their abundance, there is only little research done on the issue (Ortmann \& Heathershaw 2012; Kalmre 2013a: 18-19), and this study seeks to fill this gap.

Today's lore is based on stories and beliefs that were known already long ago in more or less recognisable form. Typical examples of negatory rumours known from history refer to beliefs about the death or secret life of a leader or celebrity. The beliefs rely on a simple psychological mechanism: we both deny and fear the death of known persons, and also toy with the idea of hated leaders' undercover, secret life. ${ }^{6}$ The characteristic feature of negatory rumours is the hypercritical pattern of thinking - this is evident in the suspicions about both real and imagined events that are described in the stories. Negatory rumours open up or expose another reality, truer than the present one. It means that every negatory rumour is coupled with an assertive rumour, replacing the denied reality with a new one. It is indeed difficult to provide evidence for this other reality, as Renard (2005: 225) asserts, not because this other reality is an illusion, but because proofs are systematically being suppressed or hidden. As a result, speculations concerning the whereabouts and identity of the targets of rumour arise: the dead are actually not dead or the living are in fact dead, being replaced by their lookalikes, etc. (ibid.: 224-226). 
Negatory rumours and legends about political figures are very similar to stories about pop idols. The rumours include their death, lookalikes, resurrection, etc. Folk theories and rumours about Elvis Presley being still alive present a case in point. They convey beliefs about a second reality within the society obsessed with entertainment; a reality where no wish remains unfulfilled. Such rumours are based on the deification of the hero (usually after their death, but in some cases also before it) and their composition can in many ways be traced back to the stories about the figure of Jesus Christ (Dundes 2007). The pop hero lives as if in two worlds - in the one we live in and in another one created by the media and popular culture through photographs, movies, and advertisements. In that beautiful desired world heroes live on after their death as idols and objects of consumption (Stromberg 1996: 290-295). This is the ground that has given rise to mythology about Putin (see Arkhipova 2015). It carries characteristics similar to stories about the Belarusian president Lukashenka and other authoritarian leaders (Astapova 2016).

We need to keep in mind, though, that deification of pop idols that are created by people themselves primarily for entertainment and pleasure purposes differs from the cult of political leaders, whose image is more serious, as is their profession and role in society. Let us compare, for example, rumours about Putin to those about the death of Stalin and/or his replacement with a lookalike. Stalin's person had been mythologised in several different ways: he was an omnipotent god, but also a monster and trickster. Attitudes towards him showed a mixture of devoted admiration and mockery, envy and anger (Kalmre 2013a: 48; see also Krikmann 2003: 94-95). His death was both hoped and feared for. Arvo Krikmann has described the phenomenon of Orwellian "doublethinking" based on the stories about Stalin's noble descent. This notion involves both fanatical worship and paralysing fear of the leader (Krikmann 2003: 195; see also Kalmre 2013a: 50). People remember the cult of Stalin as something all-embracing and powerful:

We were taught...above all, we were taught to love Comrade Stalin. The first letter we ever wrote was addressed to him in the Kremlin. Here is how it happened... Once we had learned the alphabet, they handed out white sheets of paper and dictated a letter to our most benevolent, most beloved leader. We loved him so much, we really believed that he would answer our letters and sends us presents. Lots of presents! We would stare at his portrait and think he was so handsome. The most handsome man in the world! We even argued over who would give up more years of their life for a day of Comrade Stalin's. (Alexievich 2016: 231)

We can notice that some elements are the same (depicting Putin as an omnipotent god, a cult figure as well as a joke character), but Putin's cult also 
bears features similar to the worship of pop idols or that of Western politicians (e.g. Reagan; see Street 2004 on celebrity politicians). During his 16 years in office, he has become an idol, a sex symbol, and a superhero due to his public relations team and their clever and skilful media strategies. Songs are created about him, he flies with the cranes, dives into the depths of water as an archaeologist, plays with a tiger, rides horses bare-chested in scenic locations. At the same time, he has become the central figure in Russian political humour and now embodies numerous stereotypes known from previous leaders in the state's history (Mallinen \& Hytönen 2015: 8-9). This is quite expected in the atmosphere of suppressed self-expression and censorship and a limited right to participate in political life. Thus, next to the officially circulated, flattering images of Putin, there are the ironical and humorous ones that compete with the former (although the audiences may not completely converge). Grassroots journalism is prone to use an ironic stance that Frank (2011: 166-188) captures in his notion of folk media criticism. Newslore as a form of folk media criticism contains a mixture of entertainment, explanations, and hypotheses. This easily breeds humour, mixing together different genres, which in turn are motivated by the sandwiching of serious news between commercials, serials, comedies, and other essentially incompatible genres (see Davies 1999; Ellis 2005; Kuipers 2011; Oring 2003). These different genres (including jokes, rumours, and legends) are forms of collective behaviour and ways of relieving social, political, and economic tensions and, as such, tell a great deal about the society. Gary Alan Fine (2007: 5) posits that researching rumours "reaches the heart of what it means to have a public sphere, a space of common discourse in which a community collectively judges whether truth claims are to be accepted and responded to". The genres also get along well: they provide the necessary living conditions for each other, address the same topics with a different degree of belief, they spread information and knowledge, and they help negotiating the hardships of everyday life (Ellis 2005: 126 and elsewhere; see also Best 2005). The plots of beliefs and rumours solidified in the collective memory find a suitable outlet in the visual humour on the Internet.

Laughter performs two major functions in this simultaneous struggle for both the truth and entertainment - it challenges power hierarchies and draws new audiences, expanding the circle of those protesting against the way the media present the news (Makarychev 2013: 654). The images of the ridiculous Other (caricatures, photoshopped images or mashups, etc.) contest the established power hierarchies. As a reaction, power might strike back: there have been cases of punishing acts of humorous diversion in Russia, the punk group "Pussy Riot" being the most notorious example of anti-Putin and -government actions being sanctioned (Gabowitsch 2013). Humour as a way to subvert power 
is acknowledged as a potential risk by joke-tellers as well (for a Belarusian example, see Astapova 2015: 38).

Aleksandra Arkhipova (2015) claims that people create political mythological narratives of their leaders if they believe their life and health depends on the autocrat. During late years of socialism, gerontocracy sparked stories about the ailing, dying leaders of Russia. When Leonid I. Brezhnev, Yuri V. Andropov and Konstantin U. Chernenko died in quick succession, the public was among the last to be informed. While usually the health of heads of state in other countries is public knowledge, and citizens have the right to know when and why their leader is in hospital and who runs the state in their place, then in the case of Russia these questions are subject to mystification.

It is interesting that the belief in the lookalikes of politicians can be interpreted differently. This collective belief is tied to the phenomenon of death and partly also deification, but whereas the popular heroes are suspected of still being alive (though undercover), then the politicians' lookalikes bring forth another side of the issue: it might not be the politicians themselves who are to be blamed for the mismanagement of the country but instead it is the fault of their doubles or subordinates (Mallinen \& Hytönen 2015: 12). This motif of lookalikes has been very productive. It has given inspiration for fictional texts, for example, movies (there is a film about Lenin's doubles, built on the theory that Lenin had been long dead before the revolution started (Kalmre 2013b: 37; see also My Lenins, Estinfilm 1997). There were also rumours about Yeltsin's death; for example, that he had been dead since August 1999 (when Putin succeeded him as President) and his doppelgänger acted as him until 2007. ${ }^{7}$ All in all, we can say that the reputed death, disappearance, doubles, and secret life of heroes have been and still are the most productive and prominent topics in belief narratives and culture in general. It is an endless source of inspiration for the entertainment business and social media today.

\section{REVERBERATIONS OF PUTIN'S DISAPPEARANCE IN OFFICIAL NEWS SOURCES AND TWITTER}

The time period covered in this study ranges from March 5 until March 25, 2015. The aim was to get an overview of reactions from all the phases of the media event (the beginning, peak, and end). Overall posting frequency shows that there were not many rumours, stories or other kind of reactions until March 11; they peaked in the following five days and lasted well after Putin's appearance on March 15 (or even peaked the second time, in the case of Russianlanguage tweets; see Fig. 3), gradually disappearing later on. This follows the 
usual popularity curve of internet memes (Bauckhage 2011). To contextualise the stories that arose about Putin's disappearance, let us first look at the official global media coverage and then turn to the alternative information and entertainment channel, namely Twitter.

\section{Analysis of news with the GDELT}

The GDELT (Global Database of Events, Language and Tone, founded by Kalev Leetaru in 2013) ${ }^{8}$ comprises news texts covering more than 30 years, and collecting news from 64 languages from all around the world. It offers a variety of tools and services that allow to visualise, explore, and export the data. The GDELT analysis shows that intensive news coverage of the incident started on March 10, first in the Russian-language press. North American press soon followed, peaking on March 12, but the number of news texts published in Russian press remained higher (see Fig. 1). A visualisation of the data in Gephi revealed two main, sparsely interconnected sets of news texts: largely the Russian-language / neighbouring Eastern European countries versus Englishlanguage / the rest of the world. This shows that the media of these two regions refer mainly to sources within the regions and do not refer to each other across the imaginary borders.



Figure 1. Keywords 'Putin' / 'info: rumour' / 'Russia'; combined search on the GDELT. Most of the sites are from Russian-language media (accessible for audiences who speak Russian). 


\section{Analysis of social media: Twitter threads \#PutinUmer and \#WhereIsPutin}

The aim of analysing the Twitter feed during Putin's ten-day disappearance was to compare English- and Russian-language channels, looking at the rumours that evolved, their intensity and content, and the visual format they took. This gives an insight into the global character of the rumours and humour around the disappearance of Putin, and helps to indicate the local features that accompanied their representation. Through the use of the two hashtags, \#PutinUmer and \#WhereIsPutin, tweets spread quickly.

There are some characteristic features to the Russian media that shaped the public reception in that area, especially the gap between the state-controlled media and a relatively free online sphere, but also a distinct audience divide of not only online/offline but also younger/older generation, with television and its viewers being supporters of the regime, and the internet audience the opponents (for an in-depth discussion, see Oates \& Lokot 2013). Thus the Twitter reactions studied here are mostly representative of the ideas and beliefs of the younger, technologically savvy media generation. These contrasts and social cleavages do not apply to the English-language coverage of Putin's disappearance.

The overall tendencies of dissemination of \#PutinUmer and \#WhereIsPutin are visualised in Figure 2, which depicts the different durations and intensities of tweeting about the event in the English or Russian language. There was a considerable overlap of themes and images in the two channels, which shows that cross-referencing between Twitter hashtags of various origin and in different languages might be more frequent than in the case of traditional media (e.g. as compared to the GDELT results, which suggest there was not much overlap between Russian and all other media).

The analysis of the Twitter threads shows that the hashtags in question discuss similar topics, although the sharing starts earlier and lasts longer in \#PutinUmer, whereas it starts later and is more intensive in \#WhereIsPutin. The most usual first reaction is to question the truth value of the news. Twitter users ask one another: "Is he really dead?" Being unsure about the answer, but already critical about the media that spread the news, they reply: "Who knows, but Twitter has definitely already buried him." State symbols were brought to bear: it was rumoured that the flag was missing from Kremlin tower - a sign that something had happened in the government. Additional tweets hinted that the flag was being washed because it had been stained with blood (after the alleged coup). Alternative theories posited that Putin was either ill, very seriously ill, had had a heart attack (possibly from the excessive use of Viagra - another example 


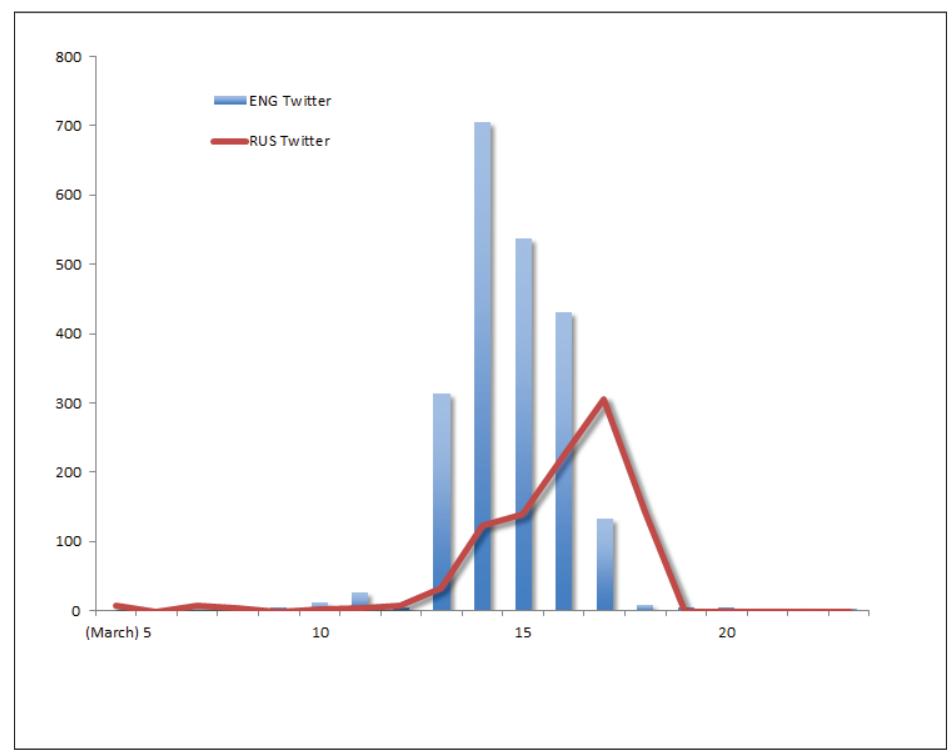

Figure 2. Russian- and English-language Twitter hashtags \#PutinUmer and \#WhereIsPutin, posts per day, from March 5 to March 25 (both text and images). ENG Twitter = \#WhereIsPutin, represented in the figure with a line; RUS Twitter $=$ \#PutinUmer, represented in the figure with columns.

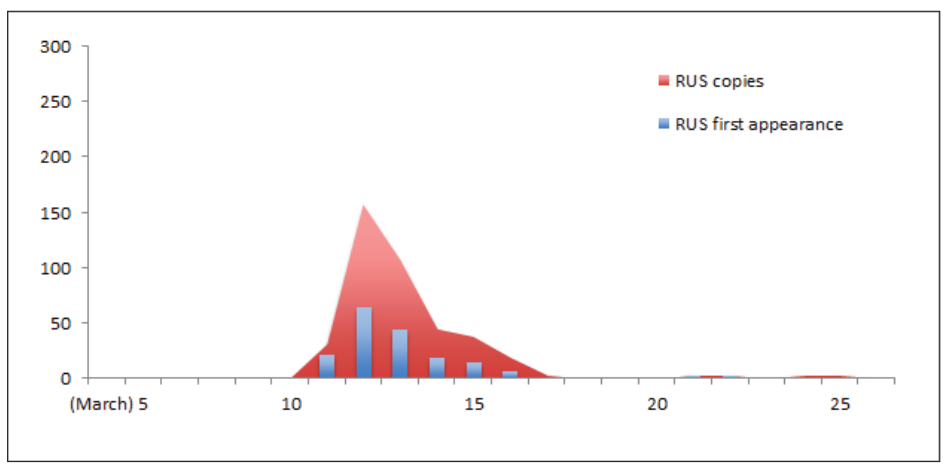

Figure 3. \#PutinUmer: total of memes (area) and first occurrences (columns).

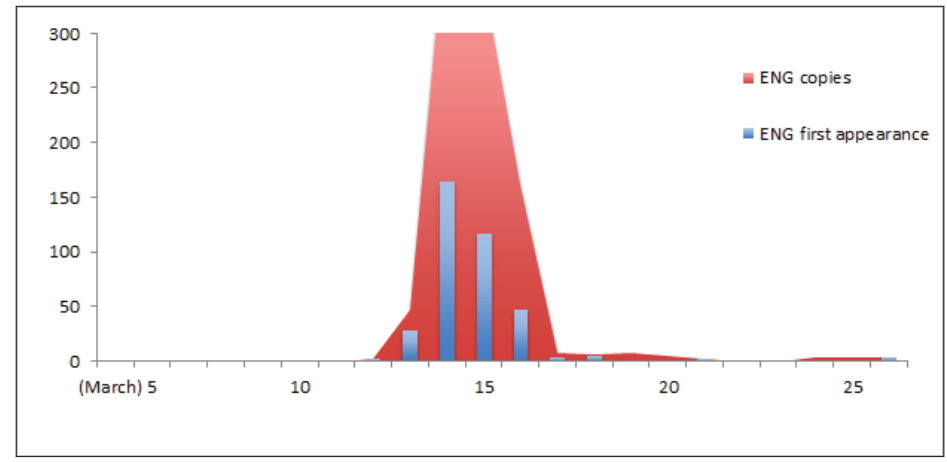

Figure 4. \#WhereIsPutin: total of memes (area) and first occurrences (columns). 
of the foregrounded (although dubious) masculinity of Putin), was dead, had been deposed by a former advisor, was planning an international military attack, was present at the birth of his love child (with Alina Kabaeva), was having (another) plastic surgery, etc. References to popular belief were present; for example, hearsay about astrologists having foreseen that Russia will lose its leader in 2015, or allusions to Friday 13 as a significant date, which was also the most intensive day of news coverage about Putin both in the official media and Twitter.

Serious discussions were replaced by humorous ones after a few days. Here, the English-language hashtag for sending memes was used with greater intensity than the Russian one (see Figs. 3-4).

It is the death of the omnipresent and -potent leader that worried the people most. He was portrayed on his deathbed, in the coffin, at a funeral, in a mausoleum, while the visual elements used were borrowed from various genres (comics, documentary photography, or even medical realm, e.g. radiology). As the crisis in Ukraine was still in full swing at the time, numerous tweets connected Putin's disappearance to this political conflict, some of them addressing it through humour (Figs. 5-6).



Figure 5. Putin has choked swallowing Ukraine - represented by the colours of the Ukrainian flag (blue and yellow) in his throat (Twitter, March 12, 2015).



Figure 6. Put in: Very soon in children's stores all across Ukraine (Twitter, March 13, 2015). 
Others are less openly humorous, presented as clever and skilful collages and mashups, peppered with references to previous Russian leaders. A closer look at these images reveals that the background for the two "bodies" is the same (Figs. 7-8).
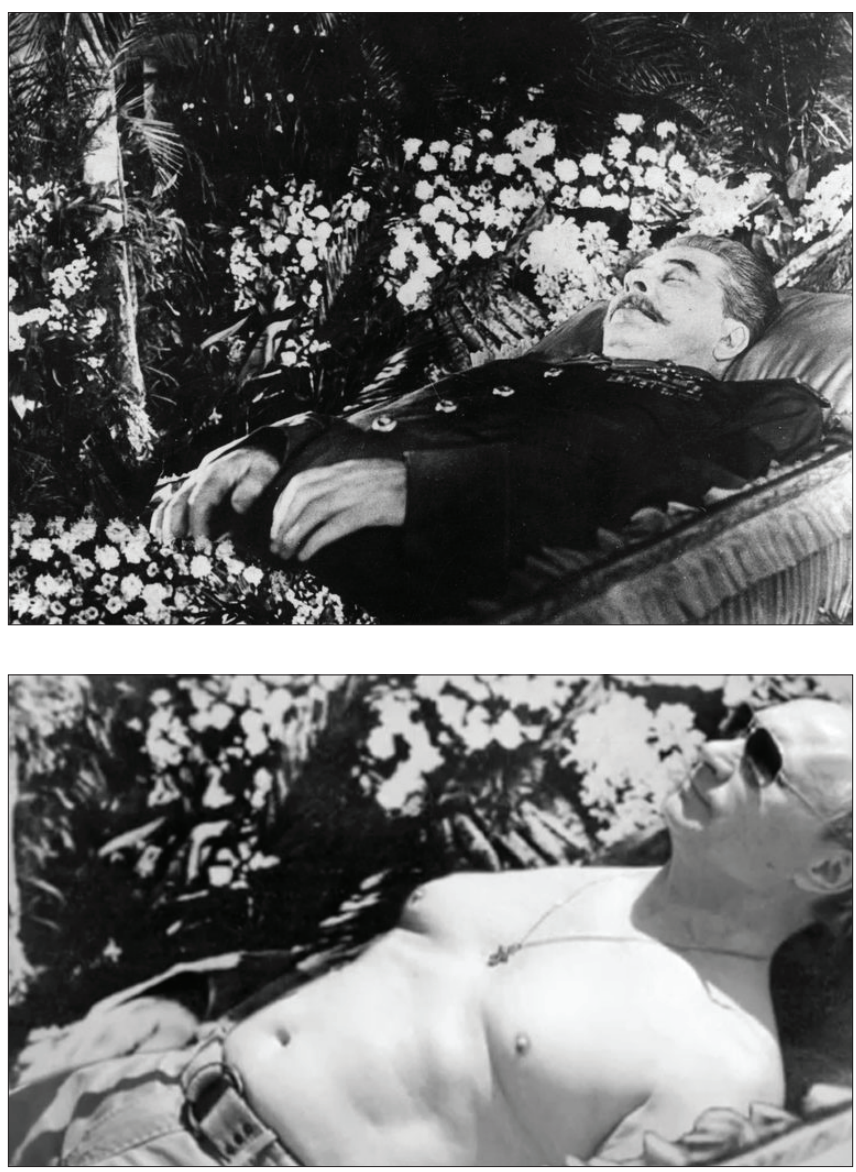

Figures 7 and 8. Stalin (original; http://mrelliottscoldwar.weebly.com/stalin.html) and Putin (collage; https://pbs.twimg.com/media/B_2PV1TVEAAoYls.jpg).

Yet others offer new images, which do not rely on prior acquaintance with the Russian culture or the funeral traditions of local leaders, but present a universally understandable visual answer to solve the mystery of Putin's disappearance (Fig. 9). 


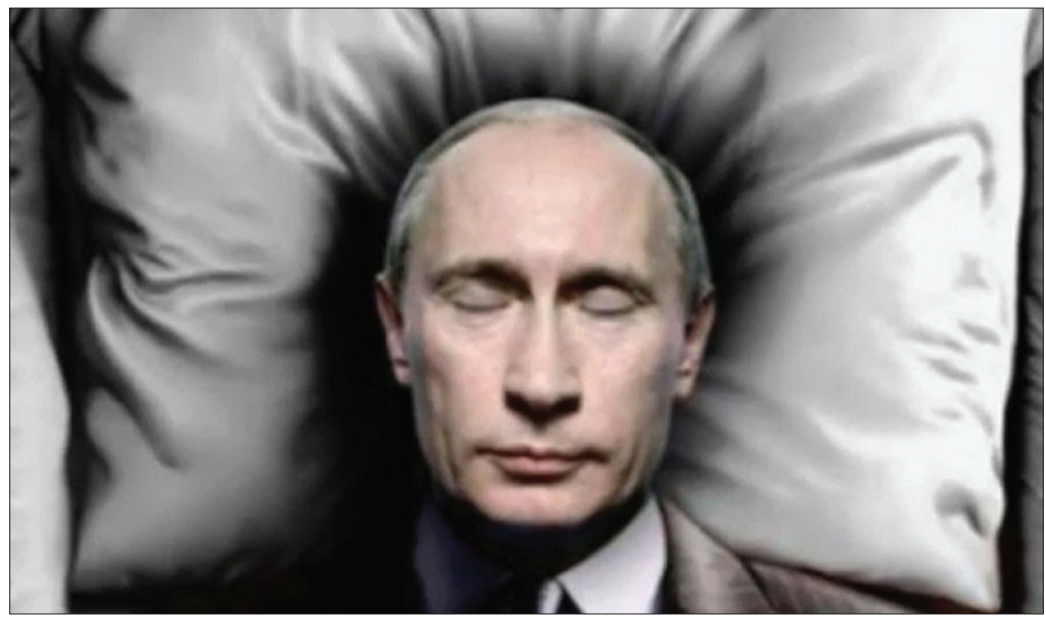

Figure 9. Putin in a coffin (https://inmoscowsshadows.files.wordpress. com/2015/03/putindead.jpeg).

An alternative stream of messages acknowledges the fact that Putin is missing, but suggests that reasons for it are unclear. As long as there is undeniable evidence that he is dead, him being missing may mean various, sometimes highly creative or totally absurd options, serious or funny. It is significant that some of the first tweets (images) point at his inactivity in social media: "Putin missing? Putin's Twitter not updated since March 6th" ${ }^{9}$ Others list a number of available hypotheses: "Five theories on \#WhereIsPutin: 1) stroke; 2) coup; 3) more Botox; 4) new kid; 5) (Ukrainian version) he has been anally probed by space aliens" (Twitter, John Sweeney, March 14). Universal references abound: "Where's Waldo?"-style pictures with a hidden Putin among the characters, or "Missing Putin" written on cartons of milk in the vein of "face on a milk carton" trope often used in American culture. There are plenty of photoshopped memes expressing suspicion about the conspiracy that he has been replaced (by other people or by a cardboard effigy). People claim that identical photographs of Putin in meetings were used in the press to calm people down. For example, almost identical photographs from 2014 and 2015 circulated as memes (see Fig. 10).

People actively present their versions of who the best lookalike for Putin is (actors, animals, portraits by known artists, characters from popular culture e.g. Dobby from the novel/movie Harry Potter). All these suggestions play on the reader's cultural knowledge and provide a humorous effect by merging together seemingly incompatible spheres of meaning. 


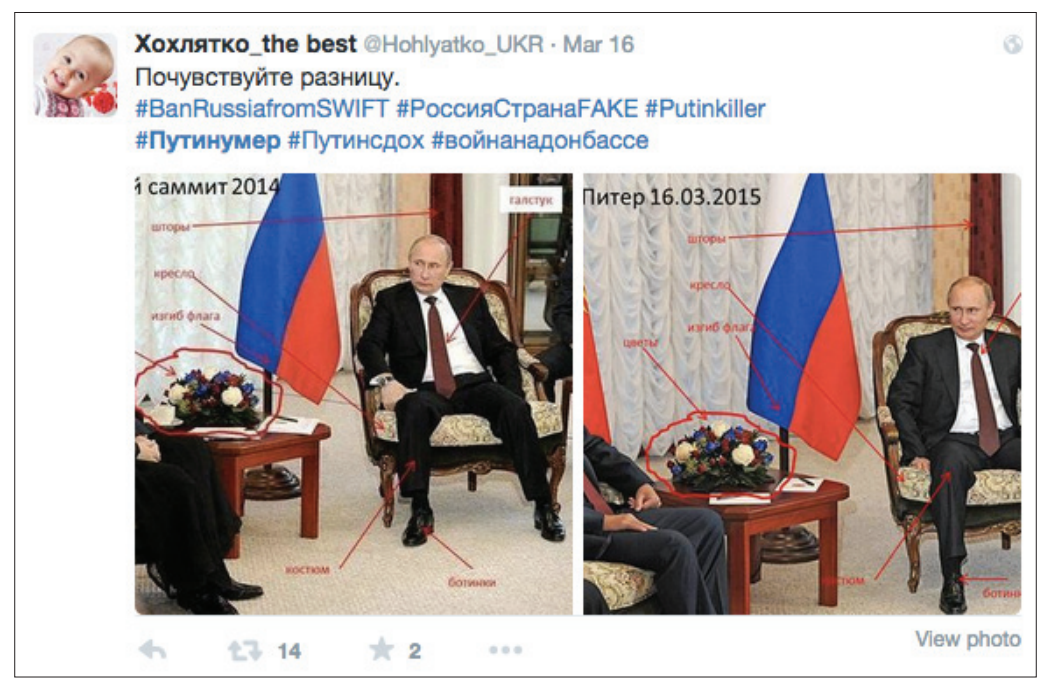

Figure 10. Identical photographs of Putin's press conferences from 2014 and 2015 (Twitter, March 16).

The second equally important and quantitatively even larger category of memes triggered by the news of Putin gone missing is that of a postmodern hypermasculine superhero taken to the extreme. This motif is inspired by Putin's character in the media discussed earlier - he is a father of the nation, wages wars and bombs the enemies, flies with the storks and rides in the outback, features in songs, artworks, calendars, etc. References to riding several objects (cookies, horses, bears, eagles, the Moon) offer an absurd visualisation of this (Fig. 11).

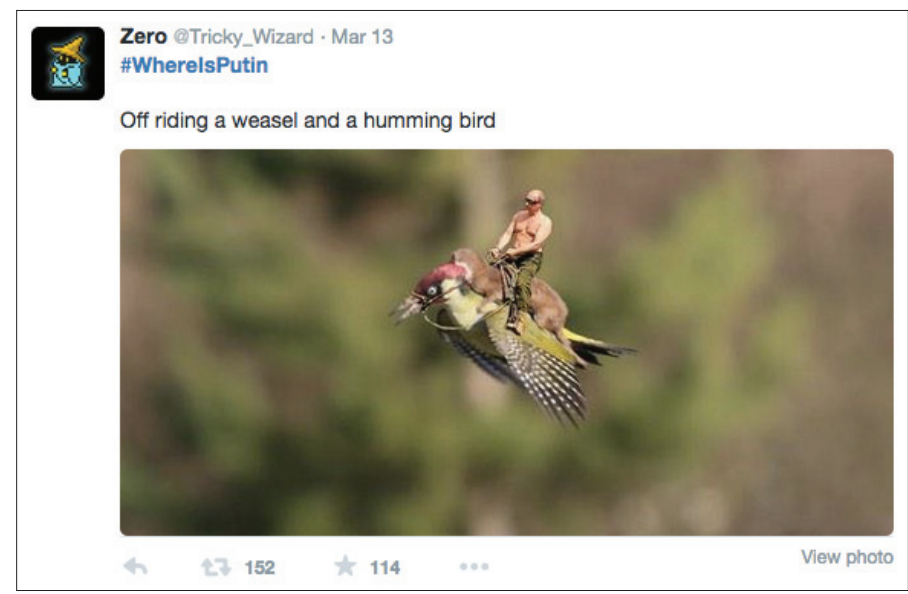

Figure 11. Off riding a weasel and a humming bird meme (Twitter, March 13). 
The meme better known under the name of WeaselPecker dates back to March 2, only a few days before Putin's disappearance, which is why it is not surprising that these two blend into imaginative remixes. Discussions abounded whether the weasel riding on a woodpecker is a fake or not (see, e.g., Bittel 2015). Harmonising pleasantly with Putin's fascination for riding and nature, the image and its numerous derivatives were some of the more popular Putin memes at the time.

References to symbols of virility were present in those images: Putin was depicted as a giant penis (see Fig. 12); yet, his masculinity was also questioned, for example in the theories that he was missing it because of the side effects of excessive Viagra. The feminisation of Putin on photoshopped images produced popular memes of Putin in a ballet skirt, with heavy make-up, or sporting huge breasts (Fig. 13). This refers to the varied hypotheses of Putin's nip and tuck surgery or Botox treatments.

Feminisation, together with state-sanctioned homophobia and traditional macho ideology, is a powerful strategy that Putin's supporters have used against the opposition, for instance, in the war with Ukraine (Romanets 2017), while his own image is that of the masculine, unbreakable man. There is a tension between the official homophobic policy advocated by the Russian government and the 'folk' depiction humorously accusing Putin of being gay. The multiple folk imagery of Putin as a woman and a gay simultaneously ridicules the official image of him as the powerful leader and a masculine man. Alan Dundes has

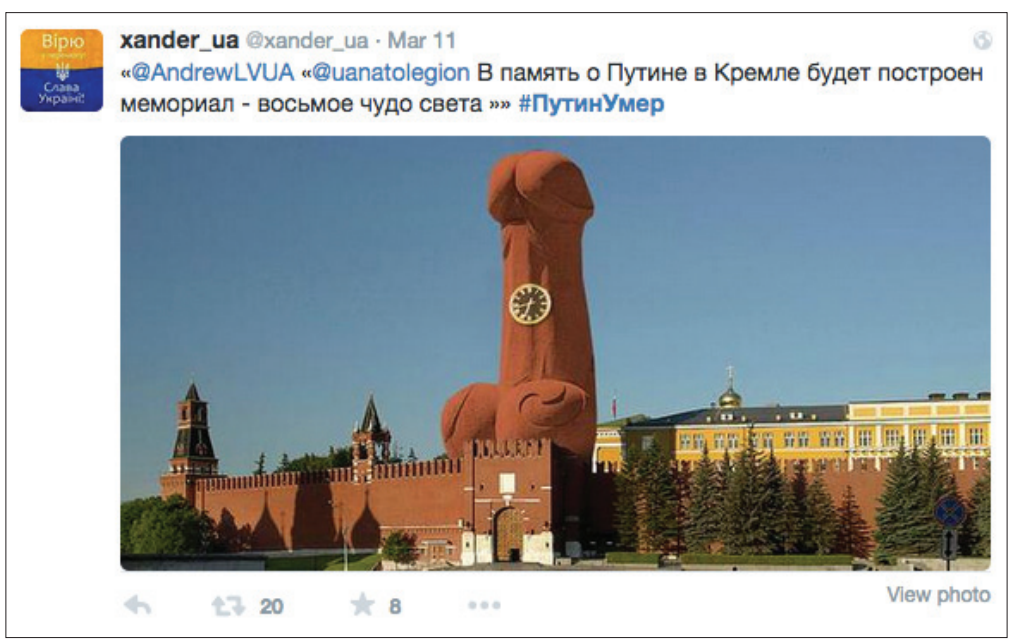

Figure 12. To commemorate Putin, a memorial will be built in Kremlin - the eighth wonder of the world (Twitter, March 11). 


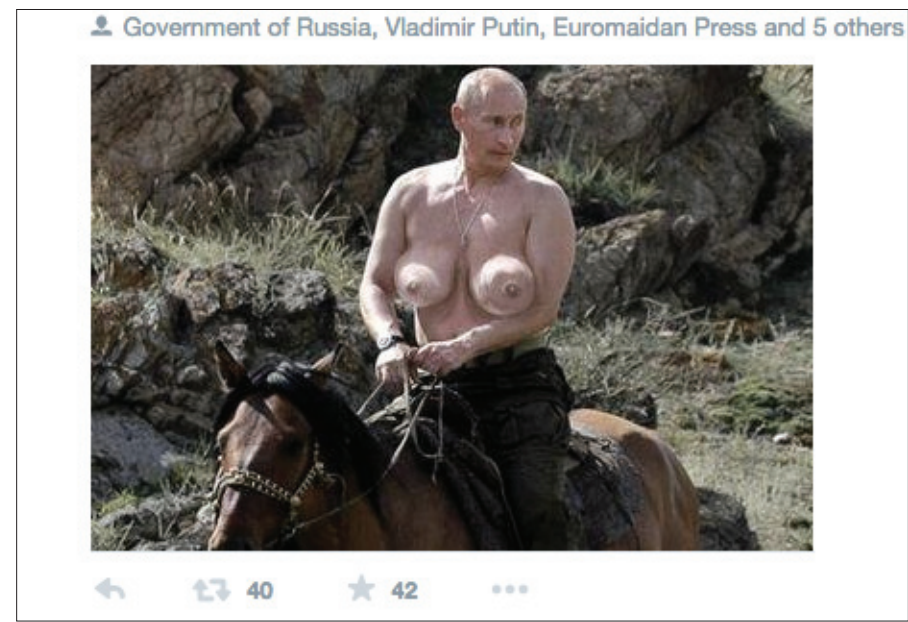

Figure 13. Putin riding a horse after aesthetic surgery (Twitter, March 13).

described similar processes in American football, where the feminisation and stigmatisation of the competitor is a strategy to gain the upper hand (Dundes 1978: 79, 85, and elsewhere). A clear use of the hypermasculinity motif was present when Putin's spokesman Mr. Peskov commented on the disappearance to the journalists and used an old 'joke' from Yeltsin's time. Namely, when Boris Yeltsin had gone missing once again, he was said to still have a firm handshake and be busy working on documents. Peskov tuned this up a little and added, "Mr. Putin's handshake could break hands" (MacFarquhar 2015).

\section{CONCLUSION}

The comparison between the content of the two hashtags, \#PutinUmer (Russian-language) and \#WhereIsPutin (English-language) highlights a number of features specific to either Russian- or English-language tweets. Firstly, the Russian-language Twitter thread was more constrained and cautious. There were questions (particularly in the beginning) about whether it was really happening or whether it was true, but no one was ready to give answers. Secondly, it dwelled longer on the possible theories of why Putin was missing, discussing their truth value, referring back to different symbols (the missing flag on Kremlin tower, Stalin's death date - March 5 - coinciding with the date of Putin going missing, etc.) to find support to these hypothetical scenarios. Thirdly, there were numerous references to earlier motifs from folk belief, rumour, 
and other elements of popular culture that are known strictly within Russian cultural space (e.g. Tchaikovsky's ballet "Swan Lake" being on TV - according to common knowledge in Russia this is usually shown when the government wants to hide something, a statement bordering between a rumour and a joke).

On the other hand, even though the English-language tweets about Putin borrowed from the Russian ones in the beginning (because the rumours started earlier in \#PutinUmer, and only later infiltrated into \#WhereIsPutin), they carried also some characteristic features, firstly greater variability of topics covered. The nationalities of the people using the \#WhereIsPutin thread were more varied, hence also the greater number and variety in the forwarded memes. Retweets reached a higher number, at times even over 300 (compared to some dozens in \#PutinUmer). Secondly, the focus was above all on conspiracy stories - the more unreal and absurd the better (clones, doppelgängers, lookalikes, beauty surgery, etc.). The exaggeration of the issue added a strong humorous overtone (contrary to the initially rather constrained style in Russian-language tweets). Thirdly, the variety of specific folk rumour references was not that big in \#WhereIsPutin. This is understandable, given that the Russians are much more intimately acquainted with the Russian leader-related myths and theories (e.g. the Swan Lake reference which is very specific to Soviet times). Last but not least, there were numerous references to Western pop culture symbols, icons, texts, and popular memes of the time.

Sharing images was common to both Russian- and English-language channels (e.g. Fig. 10, Putin in a press conference). There were cross-references to theories and jokes, and an active communication went on between the users of the two hashtags.

The comparison shows clearly that even if the world is a 'global village' and news, travelling fast, quickly become known around the world, there is a fissure between the content and the ways that particular events or cases get represented in the official media outlets and social media. The differences arise from the cultural and historical context of the producers and consumers of the news: collective memory, folklore, vernacular belief, etc. The elements visible in the top layer of daily interactions - sometimes disseminated through humour - are actually informative of the deep, entrenched layers of culture.

The question that interests us is why rumours about Putin take off so easily. The reasons are at least fourfold. Putin is an autocratic leader who holds and executes power in Russia, thus the change in leadership would cause great changes. Even if that was to please some people from the opposition, such changes would still make the society nervous. In addition to this, Putin is omnipresent in Russian mediascape and his lengthy and unexplained absence is always significant for the (local) public. Furthermore, official explanations do 
not always satisfy people because Putin's politics concerning the press gives prevalence to government-minded channels, and many people do not trust the news. The depiction of Putin in various media differs across sources: Simons (2014) has described how conservatives in the United States consider the current president of Russia an honest, courageous man with high ideals about his state and nation. For the majority of Russians, he is portrayed as the Father of the Nation (Mikhailova 2013), with only an occasional tinge of irony (Goscilo 2013). In the international media, however, Putin is represented as a negative character (Simons 2015: 205; for a discussion of exceptions, see Simons 2014).

As Russia did not develop into a democratic and open society after the Soviet Union's demise (and its mainstream media as well as the majority of alternative media channels ${ }^{10}$ are under state control), rumours about the political leaders and the economic and political circumstances still disseminate covertly. Addressing or researching them freely is problematic. It is important, however, for the society to study collective beliefs expressed through rumour because through these stories a great deal can be found out about that society (Kalmre 2013a: 23). As collective talk, rumour is tied to ideas of how society should be properly organised. Rumours like jokes give an opportunity to talk about things that would otherwise be quieted; they convey messages that would be difficult or impossible to express directly (Neubauer 1999: 169; Oring 2016: 117). Rumours that help to verbalise fear and uncertainty are especially important for people living in undemocratic and authoritarian societies. In some circumstances, we incorporate rumours into our belief system, act upon them, and recall them through collective memory (Fine 2007: 5-6) more than in others. The official media and rumours can mutually reinforce each other in a symbiotic relationship (Emde 2005). Social media comprises a huge community with a multitude of smaller sub-divisions, connected as a giant network pulsing with information. It makes all information increasingly accessible to people worldwide, doing it usually quicker than the traditional media. Consequently, news reporting becomes more emotional, faster, and personal. The Arab Spring, the Occupy Wall Street movement, Tahrir Square, the Euromaidan events in Ukraine, and many others are but some examples where grassroots journalism played a huge and influential role.

In order to explain the rumours about President Putin, his historical predecessors and folkloric belief concerning Russian rulers have to be examined. The same factors are at stake that gave rise to legends about Stalin, Brezhnev, Yeltsin or the tsars prior to them. Putin's shaping into a full-blown folk hero started hand in hand with his sudden coming to power in the year 1999, and since then the process has taken almost ridiculous dimensions. The mass media 
makes sure that the wider public is constantly being informed about the details of his life. This gives an illusion that everything is known about him - or that actually nothing is known, as we dig deeper into the information. There are many theories about his origins or private life, but no marker of their truth value. The elements of his early life and later relationships are being constantly reinterpreted (a tendency similar to a number of known figures). These so-called vernacular biographies are by no means clear-cut stories of a hero; rather, they are a medley of official representations, altered narratives, literary productions, and quotes ascribed to that person (Astapova 2016). The stories are propped up by real, strong emotions - love, fear, and hate. ${ }^{11}$

In Putin's case there are always sources to refer back to: the collective history, belief narratives, and memories about the previous leaders in Russia function as a vast pool of stories. Arkhipova, in her essay about the connections between earlier rumours about Russian leaders, writes that all the versions of Putin's disappearance are rooted in folk stories from before - for example with Putin, as with Stalin's disappearance in 1937, people suspected him of having gotten secretly married (besides being dead or having been replaced by a lookalike; see Arkhipova 2015).

Rumours about Putin are further fuelled by motives of previous stories in the collective memory (e.g. stories about doubles or early death), gaining selective importance within the contemporary Russian media that leaves much untold. Lack of relevant information is water to the mills of people's imagination. Particularly in the countries with centralised authoritarian power structure, where one leader decides everything and where there is a general shortage of information, people sincerely believe that the health and whims of the leader decide their fate. This fact forces them to construct their reality by using known mythological models, negatory ideas, and rumours. Alongside this, people become extremely suspicious and make attempts at revealing the 'truth'. Generally, when speaking about online media, serious belief (or disbelief) tends to be marginalised there and a humorous mode prevails (e.g. Danet 1995; Danet \& Ruedenberg-Wright \& Rosenbaum-Tamari 1997). Drawing from the present study, the entertainment/infotainment value is definitely foregrounded on the Internet, especially in the non-Russian material. 


\section{ACKNOWLEDGEMENTS}

This research is related to the research project "Narrative and belief aspects of folklore studies" (IUT 22-5) (Estonian Ministry of Education and Research, Estonian Research Council) and was supported by the European Union through the European Regional Development Fund (Centre of Excellence in Estonian Studies).

\section{NOTES}

1 See http://www.e-reading.club/bookreader.php/1037451/Pomerantsev_-_Nothing_Is_ True_and_Everything_Is_Possible_The_Surreal_Heart_of_the_New_Russia.html, last accessed on September 19, 2017.

${ }^{2}$ Grassroots journalism (also termed citizen journalism) is the practice of newsgathering and reporting by public citizens. It plays an active role in the process of collecting, analysing, and disseminating news and information (Gillmor 2004).

3 See discussions about the post-truth society, e.g. Bennett 2016 [1983].

4 "Rumours are called negative when they state facts associated with fear or hostility. We speak of negatory ideas and rumours when commonly accepted events are denied" (Renard 2005: 223).

5 "Through the power of photography, Putin is singlehandedly shaping the image of contemporary Russia. In politics, appearance is everything; words are secondary. This has never been truer than in the image-driven culture of the 21st century, when, in true nihilistic spirit, we don't believe in what we cannot see" (Bjelica 2015).

6 According to the international type index, the two main motives are A570 ("Culture hero still lives") and A580 ("Culture hero's expected return") (Thompson 1955-1958; see also https://en.wikisource.org/wiki/Page:Thompson_Motif-Index_2nd_1.djvu/130, last accessed on September 19, 2017).

7 Yeltsin might have died last year, a Russian internet media site reports (see http:// epl.delfi.ee/news/valismaa/Yeltsin-vois-surra-moodunud-aastal-kirjutab-veneveebileht?id=50822378, last accessed on September 19, 2017). This fake news also spread as a chain letter (Eda Kalmre's comment).

8 See http://gdeltproject.org/, last accessed on September 19, 2017.

9 YouTube, Elite NOW agenda, posted March 15, 2015 (see https://www.youtube.com/ watch?v=9S1Df8iQtoM, last accessed on September 19, 2017).

${ }^{10}$ During recent years, Russia has exerted control over the Internet and social networks (see Gerden 2015; Benyumov 2016).

11 This is reflected also in jokes about Stalin (see Krikmann 2004: 43), in which the totalitarian leader is shown as a lover of macabre humour at the expense of others. 


\section{REFERENCES}

Abdullaev, Nabi 2010. Medvedev Digs into United Russia. The Moscow Times, November 25. Available at http://www.themoscowtimes.com/news/article/ medvedev-digs-into-unitedrussia/424588.html\#no, last accessed on September 20, 2017.

Alexievich, Svetlana 2016. Secondhand Time: The Last of the Soviets. New York: Random House.

Arkhipova, Aleksandra 2015. Slukh o nem proshel po vsei Rusi velikoi. [Rumour about Him Spread All Over Great Russia.] Gazeta.ru, March 15. Available at https://www.gazeta.ru/politics/2015/03/15_a_6599953.shtml, last accessed on September 19, 2017.

Astapova, Anastasiya 2015. Negotiating Belarusianness: Political Folklore Betwixt and Between. Dissertationes Folkloristicae Universitatis Tartuensis 22. Tartu: University of Tartu Press. Available at http://dspace.ut.ee/handle/10062/49509?localeattribute=en, last accessed on September 19, 2017.

Astapova, Anastasiya 2016. Political Biography: Incoherence, Contestation, and the Hero Pattern Elements in the Belarusian Case. Journal of Folklore Research, Vol. 53, No. 2, pp. 31-62. http://dx.doi.org/10.2979/jfolkrese.53.2.02.

Bal, Mieke 2003. Visual Essentialism and the Object of Visual Culture. Journal of Visual Culture, Vol. 2, No. 1, pp. 5-32. http://dx.doi.org/10.1177/147041290300200101.

Bauckhage, Christian 2011. Insights into Internet Memes. Proceedings of the Fifth International AAAI Conference on Weblogs and Social Media, pp. 42-49. Available at http://www.aaai.org/ocs/index.php/icwsm/icwsm11/paper/download/2757/3304, last accessed on September 19, 2017.

Bennett, Lance W. 2016 [1983]. News: The Politics of Illusion. Tenth edition. Chicago: University of Chicago Press.

Benyumov, Konstantin 2016. How Russia's Independent Media Was Dismantled Piece by Piece. The Guardian, May 25. Available at https://www.theguardian.com/ world/2016/may/25/how-russia-independent-media-was-dismantled-piece-bypiece, last accessed on September 20, 2017.

Best, Joel 2005. Fashion, Topical Jokes, and Rumor as Short-Term Enthusiasms. In: G. A. Fine \& V. Campion-Vincent \& C. Heath (eds.) Rumor Mills: The Social Impact of Rumor and Legend. New Brunswick, New Jersey: Aldine Transaction, pp. 173-187.

Birnbaum, Michael \& Murphy, Brian 2015. Putin Surfaces after Mysterious 10-Day Absence. Washington Post, March 16. Available at https://www. washingtonpost.com/world/europe/putin-makes-first-public-appearance-sincemarch-5/2015/03/16/6088ab20-cbcb-11e4-8c54-ffb5ba6f2f69_story.html?utm _ term $=.86 \mathrm{a} 6930315 \mathrm{c} 1$, last accessed on September 20, 2017.

Bittel, Jason 2015. Weasel Rides Woodpecker in Viral Photo - But Is It Real? National Geographic, March 4. Available at http://news.nationalgeographic.com/ news/2015/03/150303-weasels-woodpeckers-animals-science-weaselpeckerphotos/, last accessed on September 19, 2017. 
Bjelica, Sanja 2015. Putin's Muscular Politics and the Power of Photography. Balkanist, May 23. Available at http://balkanist.net/putin-photography/, last accessed on September 19, 2017.

Danet, Brenda 1995. General Introduction: Playful Expressivity and Artfulness in Computer-Mediated Communication. Journal of Computer-Mediated Communication, Vol. 1, No. 2. http://dx.doi.org/10.1111/j.1083-6101.1995.tb00323.x.

Danet, Brenda \& Ruedenberg-Wright, Lucia \& Rosenbaum-Tamari, Yehudit 1997. "Hmmm...where' that smoke coming from?" Writing, Play and Performance on Internet Relay Chat. Journal of Computer-Mediated Communication, Vol. 2, No. 4. DOI: 10.1111/j.1083-6101.1997.tb00195.x.

Davies, Christie 1999. Jokes on the Death of Diana, Princess of Wales. In: Tony Walter (ed.) The Mourning for Diana. Oxford \& New York: Berg Publishers, pp. 253-271.

Demski, Dagnosław \& Laineste, Liisi \& Baraniecka-Olszewska, Kamila (eds.) 2015. War Matters: Constructing Images of the Other (1930s to 1950s). Budapest: L'Harmattan.

Dundes, Alan 1978. Into the Endzone for a Touchdown: A Psychoanalytic Consideration of American Football. Western Folklore, Vol. 37, No. 2, pp. 75-88. http://dx.doi. org/10.2307/1499315.

Dundes, Alan 2007. The Meaning of Folklore: The Analytical Essays of Alan Dundes. Edited by Simon J. Bronner. Logan, Utah: Utah State University Press.

Ellis, Bill 2005. Legend/Antilegend. Humor as an Integral Part of the Contemporary Legend Process. In: G. A. Fine \& V. Campion-Vincent \& C. Heath (eds.) Rumor Mills: The Social Impact of Rumor and Legend. New Brunswick, New Jersey: Aldine Transaction, pp. 123-140.

Emde, Sina 2005. Feared Rumours and Rumours of Fear: The Politicisation of Ethnicity During the Fiji Coup in May 2000. Oceania, Vol. 75, No. 4, pp. 387-402. http:// dx.doi.org/10.1002/j.1834-4461.2005.tb02898.x.

Fine, Gary Alan 2007. Rumour, Trust and Civil Society: Collective Memory and Cultures of Judgment. Diogenes, Vol. 54, No. 1, pp. 5-18. http://dx.doi. org/10.1177/0392192107073432.

Frank, Russell 2011. Newslore: Contemporary Folklore on the Internet. Jackson: University Press of Mississippi.

Gabowitsch, Mischa 2013. Putin kaputt!? Russlands neue Protestkultur. Berlin: Suhrkamp Verlag.

Gerden, Eugene 2015. Russia to Strengthen State Control over the Internet. SC Media UK, April 20. Available at https://www.scmagazineuk.com/russia-to-strengthenstate-control-over-the-internet/article/537529/, last accessed on September 20, 2017.

Gillmor, Dan 2004. We the Media: Grassroots Journalism by the People, for the People. Sebastopol, CA: O'Reilly Media.

Goscilo, Helena 2013. Putin's Performance of Masculinity: The Action Hero and Macho Sex-Object. In: Helena Goscilo (ed.) Putin as Celebrity and Cultural Icon. Abington: Routledge, pp. 180-207.

Kalmre, Eda 2013a. The Human Sausage Factory: A Study of Post-War Rumour in Tartu. Amsterdam \& New York: Rodopi. 
Kalmre, Eda 2013b. Rumours and Contemporary Legends as Part of Identity Creation Process. In: Liisi Laineste \& Dorota Brzozowska \& Władysław Chłopicki (eds.) Estonia and Poland: Creativity and Tradition in Cultural Communication. Volume 2: Perspectives on National and Regional Identity. Tartu: ELM Scholarly Press, pp. 25-42.

Krikmann, Arvo 2003. Luuseri pihtimus. [Loser's Confession.] In: Arvo Krikmann \& Sirje Olesk (comps.) Võim \& Kultuur. Tartu: EKM Teaduskirjastus.

Krikmann, Arvo 2004. Netinalju Stalinist / Internet-anekdoty o Staline / Internet Humour about Stalin. Tartu: EKM Teaduskirjastus. Available at http://www.folklore. ee/ kriku/HUUMOR/STALIN_FIN.pdf, last accessed on September 20, 2017.

Kuipers, Giselinde 2011. Where Was King Kong When We Needed Him? Public Discourse, Digital Disaster Jokes, and the Functions of Laughter After 9/11. In: Ted Gournelos \& Viveca Greene (eds.) A Decade of Dark Humor: How Comedy, Irony and Satire Shaped Post-9/11 America. Jackson: University Press of Mississippi, pp. 20-46.

MacFarquhar, Neil 2015. Putin Has Vanished, but Rumors Are Popping Up Everywhere. New York Times, March 13. Available at https://www.nytimes.com/2015/03/14/ world/europe/russia-putin-seen-in-public.html, last accessed on September 19, 2017.

Makarychev, Andrey 2013. The Culture of Protest: Counter-Hegemonic Performances in Putin's Russia. The Russian Review, Vol. 72, No. 4, pp. 653-657. DOI: 10.1111/ russ.10712.

Mallinen, Jukka \& Hytönen, Ville 2015. Putin tuli külla: Vene poliitika metsikuimad naljad. [Putin Came to Visit: Wildest Political Jokes in Russia.] Tallinn: Tänapäev.

Mikhailova, Tatiana 2013. Putin as the Father of the Nation: His Family and Other Animals. In: Helena Goscilo (ed.) Putin as Celebrity and Cultural Icon. Abington: Routledge, pp. 65-81.

Neubauer, Hans-Joachim 1999. The Rumour: A Cultural History. London \& New York: Free Association Books.

Oates, Sarah \& Lokot, Tetyana 2013. Twilight of the Gods?: How the Internet Challenged Russian Television News Frames in the Winter Protests of 2011-12. Paper prepared for the Post-Socialist and Post-Authoritarian Communication Working Group International Association for Media and Communication Research Annual Conference, Dublin, Ireland, June 2013. http://dx.doi.org/10.2139/ssrn.2286727.

Oring, Elliott 2003. Engaging Humor. Urbana \& Chicago: University of Illinois Press.

Oring, Elliott 2016. Risky Business: Political Jokes under Repressive Regimes. In: Joking Asides: The Theory, Analysis, and Aesthetics of Humor. Boulder, CO: Utah State University Press, pp. 109-128.

Ortmann, Stefanie \& Heathershaw, John 2012. Conspiracy Theories in the Post-Soviet Space. The Russian Review, Vol. 71, No. 4, pp. 551-564. http://dx.doi.org/10.1111/ j.1467-9434.2012.00668.x.

Pomerantsev, Peter 2014. Nothing Is True and Everything Is Possible: The Surreal Heart of the New Russia. New York: PublicAffairs. Available at http://www.e-reading. club/bookreader.php/1037451/Pomerantsev_-_Nothing_Is_True_and_Everything_Is_Possible__The_Surreal_Heart_of_the_New_Russia.html, last accessed on September 19, 2017. 
Renard, Jean-Bruno 2005. Negatory Rumors: From the Denial of Reality to Conspiracy Theory. In: G. A. Fine \& V. Campion-Vincent \& C. Heath (eds.) Rumor Mills: The Social Impact of Rumor and Legend. New Brunswick, New Jersey: Aldine Transaction, pp. 223-240.

Romanets, Maryna 2017. Virtual Warfare: Masculinity, Sexuality, and Propaganda in the Russo-Ukrainian War. East/West: Journal of Ukrainian Studies, Vol. 4, No. 1, pp. 159-177. DOI: http://dx.doi.org/10.21226/T26880.

Shekshnia, Stanislav V. \& Puffer, Sheila M. \& McCarthy, Daniel J. 2009. Cultural Mythology and Global Leadership in Russia. In: Eric H. Kessler \& Diana J. WongMingJi (eds.) Cultural Mythology and Global Leadership. Cheltenham, UK \& Northampton, MA: Edward Elgar, pp. 325-342.

Simons, Greg 2014. Putin's International Supporters. Ul brief No 3. Swedish Institute of International Affairs. Available at https://www.ui.se/globalassets/butiken/uibrief/2014/putins-international-supporters.pdf, last accessed on September 19, 2017.

Simons, Greg 2015. Aspects of Putin's Appeal to International Publics. Global Affairs, Vol. 1, No. 2, pp. 205-208. http://dx.doi.org/10.1080/23340460.2015.1020727.

Sperling, Valerie 2016. Putin's Macho Personality Cult. Communist and PostCommunist Studies, Vol. 49, No. 1, pp. 13-23. http://dx.doi.org/10.1016/j. postcomstud.2015.12.001.

Street, John 2004. Celebrity Politicians: Popular Culture and Political Representation. The British Journal of Politics and International Relations, Vol. 6, No. 4, pp. 435-452. http://dx.doi.org/10.1111/j.1467-856X.2004.00149.x.

Stromberg, Peter 1996. Elvis Alive? The Ideology of American Consumerism. In: Gillian Bennett \& Paul Smith (eds.) Contemporary Legend: A Reader. New York \& London: Garland Publishing, Inc., pp. 289-298.

Thompson, Stith 1955-1958. Motive-Index of Folk-Literature: A Classification of Narrative Elements in Folktales, Ballads, Myths, Fables, Medieval Romances, Exempla, Fabliaux, Jest-Books, and Local Legends. Vols. 1-6. Bloomington: Indiana University Press. 